\title{
CYP2C19*5 Allele
}

National Cancer Institute

\section{Source}

National Cancer Institute. CYP2C19*5 Allele. NCI Thesaurus. Code C45609.

Human CYP2C19*5 allele is located within 10q24.1-q24.3 and is approximately $90 \mathrm{~kb}$ in length. This allele, a variant form of the CYP2C19 wild-type allele, encodes cytochrome P450 2C19*5 protein. The CYP2C19*5 allele exhibits a clinically-relevant SNP (c.1297C>T) in exon 9 that results in a R433W coding change in the heme-binding region of the protein. This alteration in protein sequence abolishes the enzymatic activity of the cytochrome $\mathrm{P} 450$ 2C19*5 protein. 